\title{
Second Trimester Amniotic Fluid Protein Values from Normal, Neural Tube Defect, and Fetal Demise Pregnancies after Exclusion of Maternal Blood Contamination by Testing for Pregnancy-associated Macroglobulin
}

JAMES E. HADDOW, ${ }^{*}$ F. SUSAN COWCHOCK, JAMES N. MACRI, MARK MUNSON, PATRICIA BALDWIN, AND NANCY ALDRICH

Neural Tube Defect Laboratory, Nassau County Medical Center, East Meadow, New York; Thomas Jefferson University, Division of Medical Genetics, Departments of Medicine and Obstetrics and Gynecology, Philadelphia, Pennsylvania; and Rheumatic Disease Laboratory, Maine Medical Center, Portland, Maine, USA

Summary

To establish normal parameters, we have measured 14 proteins in 120 amniotic fluid samples from normal second trimester pregnancies. Pregnancy-associated macroglobulin (PAM), identified in 15 samples, has served to indicate contamination with maternal blood; this represents the first time that PAM has been used for this purpose. Albumin, transferrin, $\alpha$-1-antitrypsin, orosomucoid, IgG, and C3 show great variability in individual concentrations but are. generally in proportion to each other, particularly transferrin/albumin, $\alpha$-1-antitrypsin/albumin, and IgG/albumin. The first two ratios are similar to proportions in adult serum, supporting the concept that most amniotic fluid protein is maternal in origin and moves directly across the amnionic membrane. Levels of low density lipoproteine, C4, IgA, IgM, $\alpha$-2-macroglobulin, and haptoglobin, all low in amniotic fluid, vary independently both of albumin and of each

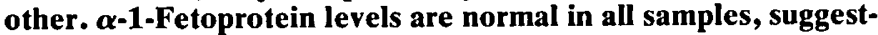
ing freedom from gross fetal blood contamination. In the presence of maternal blood contamination, 10 of the 15 samples show clear elevation of at least one protein level; $\mathrm{C3}, \mathrm{IgA}$, and $\alpha-2$-macroglobulin are most frequently abnormal.

Similar protein analyses have also been carried out on 11 samples from pregnancies with anencephaly, 5 with spina bifida,

\footnotetext{
* To whom requests for reprints should be addressed at: Rheumatic Disease Laboratory, Maine Medical Center, Portland, Maine 04102 (USA).
}

and 3 with fetal demise. Results have been compared with normal and blood-contaminated samples. Most protein concentrations are either high normal or abnormally elevated with anencephaly and fetal demise but not with spina bifida. Of all proteins studied, low density lipoprotein is most reliably elevated with neural tube defects and demise and is least affected by blood contamination. IgM and $\alpha-2$-macroglobulin are also elevated in a significant percentage of uncontaminated samples. Increased IgA and haptoglobin levels correlate with blood contamination but not with neural tube defects. Low density lipoprotein, IgM, and $\alpha$-2-macroglobulin may be useful adjuncts in the second trimester prenatal diagnosis of neural tube defects.

\section{Speculation}

Well defined normal ranges for second trimester amniotic fluid proteins are a prerequisite for applying such measurements to diagnosing fetal dysfunction and understanding transamniotic interactions between mother and fetus. In defining such parameters, the present study first re-enforces the necessity to identify blood contamination and then establishes low density lipoprotein, IgM, and $\alpha$-2-macroglobulin measurements as potentially useful ancillary studies for the prenatal diagnosis of neural tube defects. Similar testing on samples associated with omphalocele, congenital nephrosis, esophageal atresia, and other major fetal malformations must be carried out to determine whether these measurements may be of further help in second trimester differential diagnosis. 
Since Brock's discovery of the association between fetal neural tube defects (NTD) and increased amniotic fluid alpha $1-f e t o-$
protein (AFP) levels $(6,7)$, there has been renewed interest in protein (AFP) levels $(6,7)$, there has been renewed interest in the possible use of other amniotic fluid protein measurements When elevated AFP levels are found in second trimester amniotic fluid, major fetal malformations are nearly certain to be present, the majority of these being NTD (at least in Great pritain and the United States) $(16,19,25)$. False positive AFP
Brital (a) measurements are reported to occur at the rate of 0.18 , once samples contaminated with fetal blood have been excluded (22). geal atresta may also give omphalocele, and esophaniotic fluid. Analysis of other amniotic fluid proteins repques to distinguish setween for additional diagnost

Ultrasound techniques, already widely used as an adjunct to (3). Amniography, currently used on a more limited basis, also can detect anencephaly but until recently has shown ilitso promise of delineating other AFP-related lesions (12). Macri and Weiss (31) have now documented the first actual visualization of meningomyelocele by amniography, and it is likely that this technique will find increasing application in the near future. Using a different approach, Gosden and Brock have recently reported on the use of amniotic fluid macrophage analysis to distinguish between NTD, omphalocele, and normal fetuses (17). Once confirmed, this will represent still another adjunctive technique to apply to AFP-positive second another adjunctive technique to apply to AFP-positive second
trimester amniotic fluid. Several preliminary reports have indicated that other amniotic fluid proteins (besides AFP) may be elevated during the second trimester in the presence of an NTD $(4,5,20)$, suggesting that such testing may also be an aid to more accurate and reliable diagnosis of fetal malformations.

Unlike AFP, which is specifically manufactured by the fetus, and fetal circulations $(14,15)$. Hence, to be of diagnostic significance, such proteins must be characterized not only by their concentrations, but also by their maternal and fetal contributions. Already, several major amniotic fluid proteins have been shown to be largely of maternal origin, thus dimming prospects of their diagnostic value $(21,28,29)$. As a further complication, amniotic fluid samples are sometimes contaminated wess reliable (4). Also, some amniotic fluid protein concentrations vary with gestational age (29).

We attempt, in this paper, first to define normal ranges for 12 amniotic fluid proteins during the second trimester identifying maternal blood contamination by measuring pregnancy-associated macroglobulin (PAM) (1), a protein ordinarily found only in maternal serum and not previously used for this purpose. clude gross fetal blood contamination. Next, we examine amniotic fluid samples obtained from second trimester pregnancies known to be affected with neural tube defects and fetal demise. These measurements are then compared with the normal and bloodcontaminated samples as a first step towards learning whether such measurements may be helpful in the differential diagnosis of in utero congenital malformations.

\section{MATERIALS AND METHODS}

Amniotic Fluid Samples - These were frozen after collection and were from pregnancies whose subsequent outcome was known. Ges(LMP) and was, in!most cases, confirmed by ultrasound and/or delivery date. Sample identity was by coded numbers, and informed consent was obtained in each case. A total of 120 specimens, from between 14 and 22 weeks gestation, were analy-
zed. Before testing, each sample was centrifuged at $2,500 \mathrm{rpm}$
for 15 minutes.

Assay of Proteins - Analyses were carrled out in the Technicon Automated Immunoprectpitin System (26), using antisera from Atlantic Antibodies, Inc. (Westbrook, Maine). Antisera were diluted individually in 48 polyethylene glycol for each experiment and were then put through a millipore filter. Antigen controls were prepared from a serum pool whose protein values ference material, was run each day for every protein. Controls were inserted after every twelfth sample. Most samples were tested undluted, but dilutions as high as $1: 32$ were required occasionally when antigen concentrations or blanks were high. For a given sample, all 12 proteins were analyzed on the same day.

Prior to each set of measurements, diluted antiserum was pumped through the analyzer for several minutes to establish a baseline. A setting of 506 FSR was used for all blank determinations using amniotic fluid at a flow rate of $0.1 \mathrm{ml} / \mathrm{min}$. Antibody dilutions varied with potency. For actual measurements, amniotic fluid was sampled at a rate of 0.03 to $0.1 \mathrm{ml} / \mathrm{min}$. In measured with confidence at between 0.2 and $3.0 \mathrm{mg} / 1$, depending upon the protein being studied.

AFP and PAM were assayed by the Laurell Technique (24). AFP values were derived from the who standard, and representative samples were compared with other laboratories for accuracy. PAM values were standardized against a pregnancy serum pool whose levels were quantitated in the laboratories of Dr. W.H. stimpson (Blochemistry Department, University of Strathclyde, Glasgow, Scotland) and Dr. C.H.W. Horne (Department of Pathology, University Medical Buildings, Foresterhill Aberdeen, Scotland). For both of these antigens, a 1.28 agarose gel was employed, wth antiserum concentrations adjusted to give sharp
peaks in the range desired, approximately 1.258 and 0.88 respectively.

Results - All of the 120 normal amniotic fluid samples have AFP levels within the normal range, while 15 show measurable levels
The 105 samples with undetectable PAM levels have been assayed to determine the "normal" ranges for 12 proteins. Figure 1 shows the actual distribution of concentrations within normal range for each of the 12 proteins, most demonstrating considerably more variability than their serum counterparts. Albumin, for example, ranges between 330 to $6400 \mathrm{mg} / 1$. For several of the proteins studied, a number of values fall below the limits butions are not possible except at the upper end of their concentration ranges.

Table I contains mean values and standard deviations for the 12 compared with a normal serum adult pool. In amniotic fluid, compared with a normal serum adult pool. In amniotic fluid, the lowest. The first 6 all show lower mean concentrations for 14-17 weeks than for 18-22 weeks gestation; from the second 14-17 weeks than for $18-22$ weeks gestation; from the second
group of 6 proteins, only IgA shows a similar trend. Concengroup of 6 proteins, only IgA shows a similar trend. Concentrations of several amniotic fluid proteins vary proportionally fluid albumin levels. Ratios of those amniotic fluid proteins to albumin have been individually calculated and summarized in
the table. Ratios are most consistent for transferrin, alpha the table. Ratios are most consistent for transferrin, alpha
l-antitrypsin and IgG. For comparison, Table 1 also lists ratios in an adult normal serum pool for transferrin/albumin, alpha 1-antitrypsin/albumin, orosomucoid/albumin, IgG/albumin and C3/albumin. Transferrin/albumin and alpha 1-antitrypsin/albumin are nearly superimposible in adult serum and amniotic bumin, alpha l-antitrypsin/albumin and IgG/albumin, based on Gitlin's data (14,15). Of the three, alpha l-antitrypsin's Gitlin's data $(14,15)$. Of the three, alpha 1-antitrypsin's
ratio to albumin is the most similar between fetal serum, amniratio to albumin is the most similar between fetal serum, amni-
otic fluid and maternal serum. None of the lower 6 proteins isted in Table 1 shows any tendency to vary either in proportion to albumin or to each other, and so no $r$ atios are included for them. Albumin and alpha-fetoprotein concentrations have been compared in amniotic fluid samples for each of the weeks ship exists. The two proteins have been found to vary randomiy and independently.

The 15 amniotic fluid samples with measurable levels of PAM have been analyzed separately on the assumption that they are dually for all 15 PAM dually for all 15 PAM positive samples. Of those, 10 have one or more protein values higher than the normal range, while 5
cannot be distinguished from normal. Levels of C3 and IgA are
most consistently elevated (7 each) followed by alpha 2-macroglobulin with 6 and IgM with 5, alpha l-antitrypsin and IgG (4 each), albumin, transferrin, orosomucoid and haptoglobin (3 each), 2 for C4 and 1 for low-density lipoprotein.

Table 3 gives pertinent ratios for those same 15 PAM positive samples. Only 7 of these samples can be described as abnormal elevated values respectively are the most reliable ind icators. No sample can be identified as abnormal by a ratio when ali protein concentrations are within the normal range. Converseprotein 3 samples, individual protein values are abnormally elevated without ratios being disturbed.

Individual protein values are listed in Table 4 for each of the 11 second trimester amniotic fluid samples from anencephalic pregnancies, arranged according to ascending.order of albumin concentrations. All samples with possible maternal blood contamination have been excluded from this part of the study by at approximately the normal mean, and 4 samples have abnormaliy at approximately the normal mean, and 4 samples have abnormally teins, including transferrin, alpha l-antitrypsin, orosomucoid, IgG, c3, and $c 4$, are limited to these same 4 samples. In contrast, elevated concentrations of low density lipoprotein, IgM and alpha 2-macroglobulin bear no relationship to the others. IgM in 6, and alpha 2-macroglobulin in 5. All 3 of these proteins are elevated in 3 samples, 2 of them are elevated in 5 samples and only 1 of these proteins is increased in one sample. Normal concentrations for all 3 proteins are present only in 2 of the 11 cases. Conversely, IgA and haptoglobin are normal in all 11 samples.

Similar analyses performed on 5 spina bifida pregnancies are isted in Table 5. For these, albumin values begin well below the normal mean, and all are well within the normal range. The reflow the exception of low density lipoprotein ( 3 elevated values), alpha 2-macroglobulin ( 2 elevated values), and IgM (1 elevation). In one

Results from 3 amniotic fluid samples associated with second trimester fetal demise are recorded in Table 6 . These are shown in spite of the fact that all 3 are discolored and turulin (PAM) is present in sample B. Albumin, transferrin, alph part of the normal range to abnormally high. of the total abnormal results, most are found in sample $C$. Low density Iipoprotein, however, is elevated in all 3 samples, $C 3$ and IgM in 2 , and alpha 2 -macroglobul in in 1 . Consistently low values are present for orosomucoid, C4, IgA, and haptoglobin.

Discussion - Assays of the 12 proteins used to establish normal parameters in this study have been carried out by a nephelometric technique. Sensitivity of this method is equivalent to, and in some cases greater than, the Laurell electroimmunoassay. Nephelometry is more sensitive than radial immunodiffusion, the method most of ten used in published studies of amniotic fluid proteins. For six of the proteins analyzed here, the entire normal range is measurable, but for the remainder, a significant number of samples has values below assay detection. More sensitive methods must be applied to these before they can be fully examined. Those proteins which can be satisfactorily measured have a wide range of normal. In this respect, nor
amniotic fluid differs from other body fluid compartments. 
Maternal blood contamination has been identified in 128 of our samples by testing for a pregnancy-associated macroglobulin, found in maternal but not in fetal serum; a percentage in reasonable agreement with published figures from other series (4). Since this marker has not been used previously, and since information on the original characteristics of the samples is not available, it has not been possible to correlate PAM levels and the actuai degree of contamination. Most PAM positive samples have higher than normal protein values, showing sufficient distortion of concentrations that meaningful interpretations cannot be made except for fetally derived proteins such as AFP. For evaluating possible maternal blood contamination in samples sis. A number of our PAM positive samples have elevated alpha 2-macroglobulin concentrations, an important consideration when that protein is being tested along with AFP in neural tube etection (4).

Most amniotic fluid proteins appear to be of maternal orlgin, and their passage across the amnion is governed by molecular size and configuration $(28,29)$. Disagreement exists as to the reason for amniotic membrane selectivity (3) While not resolving that question, the present study does add information on relative protein proportions on the two sides of the membrane. On the amniotic fluid side, several, including transferrin, alpha I-antitrypsin, orosomucoid, IgG and $\mathrm{C} 3$ vary in direct proportion to the amniotic fluid albumin concentration, suggesting that all are similarly regulated. Two of them, transferrin and alpha l-antitrypsin, have ratios to albumin in amniserum, indicating even greater similarity in transmembrane movement.

Low density lipoprotein, C4, IgA, IgM, alpha 2-macroglobul in and haptoglobin all exist in unfavorable proportion to their serum counterparts; and none of them shows any tendency to vary proportionally with amniotic fuid albumin levels. This lack of correlation might be due to poor assay precision in the lower part of their normal ranges. These proteins might be contamination but, in fact, they do not.

Fetal blood contamination is known to occur only occasionally (approximately ${ }^{2}$ in 100 samples). All samples in this study serum unlikely. AFP is analogous to PAM in that it is specific to one circulatory system. It cannot be used prospectively as an indicator of fetal blood, however, since the prime purpose for its analysis is to link increased levels to neural tube defects. In fact, fetal bleeding must be carefully excluded when interpreting AFP levels to avoid false positive results. Analysis of hemoglobin F, although helpful at times, is not reliable due to its dependence on hemolysis for identification. For diagnostic purposes it is desirable to have an uncentrifuged sample, so that red blood cells may be assessed not available for the present study.

Because alpha-fetoprotein's structure is so similar to that of albumin (27), it would be reasonable to assume that both are handled similarly by the amniotic membrane (3). Since amniotic fluid AFP is fetal in origin and amniotic fluid albumin is mamight possibly be reciprocally related as an expression of their equilibration across a bidirectional membrane. Attempts to demonstrate such a relationship in this study have been unsuccessful.

When compared with maternal blood-contaminated (PAM+) amniotic fluid samples, values from anencephalic (PAM-) pregnancies have a number of similarities but several important differences. Albumin, transferrin, alpha 1-antitrypsin, orosomucoid, IgG, and C3 follow similar patterns for both groups, although $\mathrm{C} 3$ is sometimes abnormally high in the PAMt samples even when the rest are normal. $\mathrm{C4}$ is out of the normal range only once in each group, while alpha 2-macroglobul in and IgM are abnormally high is a significant proportion from both groups. Three proteins behave discordantly in the two sample groups. IgA, elevated in half of the PAM+ normal samples, is always normal in the anencephalic group. Haptoglobin ranges from high-normal to elevated in the blood-contaminated specimens but is always lownormal with anencephaly. Low density lipoprotein, normal in
all but one of the pAMt samples, is abnormal in 9 of the il specimens from anencephalic pregnancies.

With the exception of a few shared parameters, amniotic fluid results from meningomyelocele pregnancies are different from both of the preceding groups. The overall pattern of protein low density lipoprotein (3/5), alpha 2-macroglobulin $(2 / 5)$, and IgM $(1 / 5)$. These 3 proteins are also consistently abnormal in anencephalic pregnancies; the latter 2 being frequently elevated also with maternal blood-contamination. The spina bifida samples, like those from anencephalic pregnancies, have lowtaminated with maternal blood.

Due to their turbidity and discoloration, the fetal demise samples may be identified by inspection. Most protein concentrations in these samples are either high normal or actualiy elevated. Like samples from anencephaly, low density lipopro-
tein. IgM, and alpha 2-macroglobulin all are elevated, while tein, IgM, and alpha 2-macroglobul in all ar
C4, IgA and haptoglobin are consistently low.

Higa et al (20) have studied total protein and 20 individua proteins in 8 samples from cases of anencephaly (31-42 weeks gestation) and 5 from fetal demise (28-39 weeks gestation). His report observes that total protein, IgM, IgA, and IgG (as
well as AFP) appear to be useful in diagnosing anencephaly and well as AFP) appear to be useful in diagnosing anencephaly and elevated in the majority of anencephalic cases; IgG only when associated with total protein increases; and IgA not at all. Discrepancies may be explained by the different stages of gestation at which the two studies have been carried out.
Measurement of albumin, IgA, IgG, IgM, AFP, and alpha 2-macroglobulin have been carried out by Cantuaria and Jones (9). On 2 meningomyelocele and 9 control amniotic fluid samples obtained during the second trimester. In this study, only IgM elevations are associated with meningomyelocele, a finding at least partially consistent with the present report. It is not surprising that he has not found alpha 2-macroglobul in in his analyses, since the technique of radial immunodiffusion would not tic fluid concentration of that protein.

In another study. Brock (4), using a "rocket" technique, has demonstrated consistently elevated alpha 2-macroglobulin values in 33 pregnancies associated with spina bifida or anencephaly from between 8 and 42 weeks gestation. Analyses of beta 1 ipoprotein and IgM have been carried out as part of the same study, yielding the conclusion that they, too, are elevated in
the presence of NTD. Brock emphasizes the possible distortion of results by maternal blood-contamination.

This problem of amniotic fluid sample contamination by maternal blood is critical, since no observations can be made confidently on protein concentrations until that possibility has been istics is often either unavailable or unreliable, and it is this fact which has led us to make use of pregnancy-associated The present study also suggests that any second trimester amniotic fluid sample having increased amounts of IgA or haptoglobin should be suspect as blood-contaminated, since
NTD nor fetal demise samples show these abnormalities.

Low density lipoprotein appears to be the most diagnostically useful amniotic fluid protein for the second trimester diagnosis of NTD and fetal demise excluding, or course, AFP. It is normal in most blood-contaminated samples, an observation for which we have no ready explanation. IgM and alpha 2-macroglobulin are also diagnostically useful, after exclusion of blood-contamination. Although neither is elevated in NTD cases as often as low density lipoprotein, measurement of all 3 proteins may be useful in an amniotic fluid sample with an elevated AFP value. Other amnlotic fluid proteins measured in this study may be helpful in understanding the amniotic fluid dynauseful for pre-natal diagnosis of neural tube defects.

\section{REFERENCES}

1. Berne, B.н.: Pregnancy-associated alpha 2-glycoprotein levels in pregnancy, oral contraception and choriocarcinoma in: protides of the Biological Fluids -24 th collo quium - ed.: Dr. H. Peeters - Vol. 24, P. $165,1976$.

2. Biswas, 5.K., and Sengupta, A.B.: Study of immunoglobulins in human amniotic fluid. Indian J. Med. Res. $63: 928,1975$.

3. Bradwell, A.R., Burnett, D. " and Williams, J.G.: A mechanism for protein movement from blo
J. Physiol., (Lond), 258:33P, 1976.

4. Brock, D.J.H.: Amnlotic fluid alpha 2-macroglobulin and the antenatal diagnosis of spina bifida and anencephaly.

5. Brock, D.J.H., and Nelson, M.M.: Amniotic fluid protein in pregnancies complicated by anencephaly. J. Obstet. Gyn. Br. Comm., 81:177, 1974 .

6. Brock, D.J.H. and Scrimgeour, J.B.: Early pre-natal diagnosis of anencephaly. Lancet, $\underline{2}: 197,1972$.

7. Brock, D.J.H., and Sutcliffe, R.G.: Alpha-fetoprotein in the pre-natal diagnosis of anencephaly and spina bifida. Lancet, $\underline{2}: 197,1972$.

8. Campbell, S., Pryse-Davies, J., Coltart, T.M., Seller, M. and Singer, J.D.: Ultrasound in diagnosis of spina bifida. Lancet, $\underline{1}: 1336,1975$.

9. Cantuaria, A.A. and Jones, A.L.: Immunoglobulin $M$ in human amniotic fluid and its possible association with neural tube
$82: 262,1975$.

10. Cowchock, F.S.: Use of alpha-fetoprotein in pre-natal diagnosis, clin. Obstet. Gynecol., 19:871, 1976.

11. Evans, H.E., Glass, L., and Mand, I.: Alpha 1-antitrypsin concentration in amniotic fluid, Biol. Neonate. $\underline{27}: 232,1975$.

12. Frigoletto, F.E., Jr., and Griscom, N.T.: Amniography for the detection of fetal myelomenigocele, Obstet. Gynecol. 44:286, 1974 .

13. Gadow, E.C., Floriani, F.A., and Florin, A.: IgG levels

14. Gitlin, D., and Boesman, M.: Serum alpha-fetoprotein, albumin and IgG-globulin in the human conceptus. J.Clin. Invest. 45 : 1826,1966

15. Gitlin, D., and Biasucci, A.: Development of IgG, IgA, IgM, BlC/Bla, Cl esterase inhibitor, ceruloplasmin, transferrin, hemopexin, haptoglobin, fibrinogen, plasminogen, alpha 1-antitrypsin, orosomucoid, beta-lipoprotein, alpha 2-macroglobulin and prealbumin in the human conceptus. J clin. Invest., $48: 1443,1969$.

16. Goldsmith, C., D'Alblaing, G., and Chandor, S.: Amnioticfluid proteins. Lancet, $\underline{1}=367,1974$.

17. Gosden, C.M., and Brock, D.J.H.: Morphology of rapidly 
adhering amniotic fluid cells as an aid to the diagnosis of neural tube defects, Lancet, 1:919, 1977.

18. Guibaud, S., Bonnet, M., Thoulon, J.M., and Duhant, M.: Alpha l-antitrypsin in amniotic fluid. Am. J. Obstet. Gyn., 45:34, 1974 .

19. Haddow, J.E.: pregnancy-related alpha-fetoprotein testing: Guidelines in usage and interpretation. $J$. Maine Med. Assoc., 67:6, 1976 .

20. Higa, Y., Sasazuki, T., Nakajima, H., Takayama, M., Tada, $M .$, and Soma, H.: Amniotic fluid proteins in the anteMatal diagnosis of some fetal abnormalities, Am. J. Obstet. Gyneco1., 119:932, 1974.

21. Johnson, A.M., Umansky, I., Alper, C.A., Everett, C.A., and Greenspan, G.: Amniotic fluid proteins: Maternal and fetal contributions. Pediatrics, $84: 588,1974$.

22. Kimball, M.E., Milunsky, A., and Alpert, E.: Prenatal diagnosis of neural tube defects III. A re-evaluation or 1977 .

23. Larsen, B., Snyder, I.S., and Galask, R.P.: Transferrin concentration in human amniotic fluid. Am. J. Obstet. Gyn., 117:952, 1973.

24. Laure11, C.B.: Quantitative estimation of proteins by electrophoresis in agarose gel containing antibodies. Anal. Biochem., 15:45, 1966 .

25. Lindsten, J., zetterstrom, R., and Ferguson-Smith, M., in: Prenatal diagnosis of genetic disorders of the fetus, I.N.S.E.R.M., Paris, 1976 .

26. Ritchie, R.F., Alper, C.A., Graves, J., Pearson, N., and Larson, C.: Automated quantitation of proteins in serum and other biological fluids. Am.J. Clin. Path., 59:151, 1973 .

27. Ruoslahti, E.: The biochemical nature of alpha-fetoproteln and its purification. Los Angeles Alpha-fetoprotein Conference - January 26-29, 1977.

28. Sutcliffe, R.G.: The nature and origin of the soluble protein in human amniotic fluid. Biol. Rev., 5g:1, 1975.

29. Sutcliffe, R.G.; and Brock, D.J.H.: Immunological studies on the nature and origin of the major proteins in amniotic on the nature and origin of the major prote
fluid. Br. J. Obstet. Gyn., BD:721, 1973 .
30. Ustaegui-Gomez, M.: Immunoglobulins and other protein constituents of amniotic fluid in: Natelson, S.,' John Wiley and Sons, New York, p. 111-124.

31. Weiss, R., and Macri, J.N.: Manuscript in preparation.

32. Received for publication, July 26, 1977.

33. Accepted for publication, November 2, 1977.
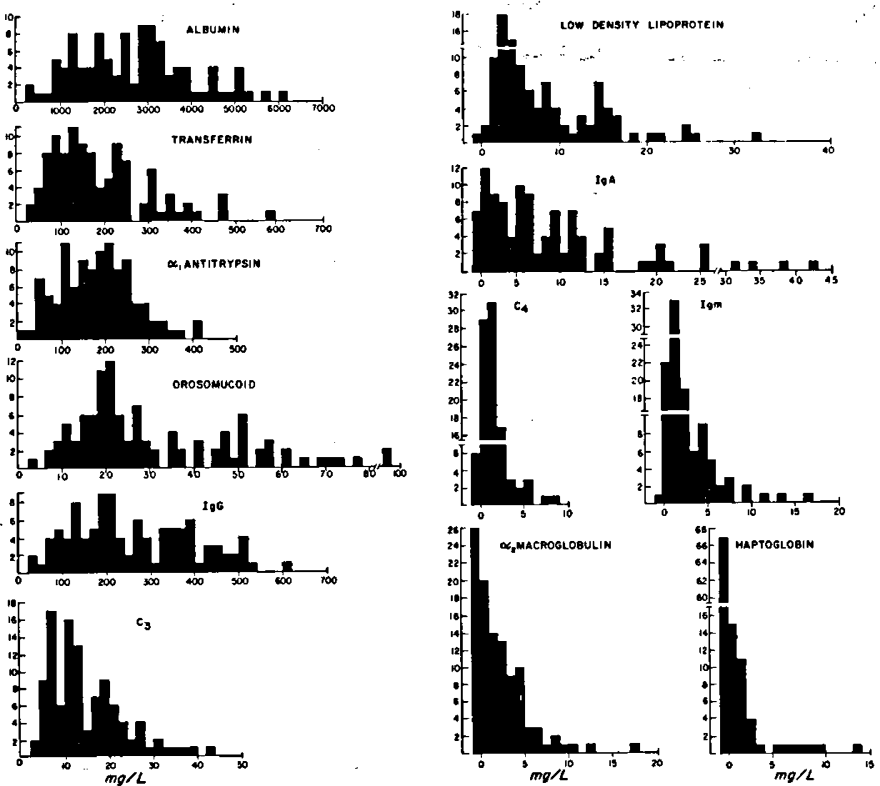

Figure 1. The range of normal values for each of 12 anniotic fluid proteins tested in 105 samples obtained between 14 and 22 weeks gestation. In each graph the vertical axis 1 numbered to represent total samples where values fall within a given concentration range on the horizontal axis.

TABLE 1

NORMAL DATA FOR I2 AMNIOTIC FLUID PROTEINS

\begin{tabular}{|c|c|c|c|c|c|c|}
\hline & $\begin{array}{l}\text { 14-17 wk } \\
\text { Mean }+1 \mathrm{SD} \\
(\mathrm{mg} / 1)\end{array}$ & $\begin{array}{l}\text { 18-22 wk } \\
\text { Mean } \pm 1 \text { SD } \\
(\mathrm{mg} / 1)\end{array}$ & $\begin{array}{l}\text { 14-22 wk } \\
\text { Mean } \pm 1 \text { SD } \\
(\mathrm{mg} / 1)\end{array}$ & $\begin{array}{l}\text { Ratio to Albumin* } \\
\text { in Amniotic Fluid } \\
\text { (all values } \times 10^{3} \text { ) } \\
\text { Mean } \pm 150\end{array}$ & $\begin{array}{l}\text { Ratio of Serum } \\
\text { Proteins to Serum } \\
\text { Albumin** } \\
\text { (all values } \times 10^{3} \text { ) }\end{array}$ & $\begin{array}{l}\text { In Fetal Serum } \\
\text { at } 16 \text { wk } \\
\text { gestation }(14,15)^{* * *} \\
\left.\text { (all values } \mathrm{x} 10^{3}\right)\end{array}$ \\
\hline Albumin & $2473^{ \pm} 1261$ & $2864 \pm 1283$ & $2665 \pm 1277$ & & & \\
\hline Transferrin & $166.6 \pm 98.3$ & $212.5 \pm 115.3$ & $188.5 \pm 109.1$ & $71 \pm 18$ & 75 & 36 \\
\hline al-Antitrypsin & $161.3 \pm 78.7$ & $200.8 \times 85.5$ & $180.1 \pm 84.3$ & $69+16$ & 66 & 80 \\
\hline Orosamucoid & $28.7 \pm 19.2$ & $33.2 \pm 19.6$ & $30.9 \pm 19.5$ & $12 \div 5$ & 25 & \\
\hline Immunoglobul in G & $237.7\{120$ & $288.7 \pm 147.9$ & $262.0 \pm 136.3$ & $88 \div 24$ & 275 & 40 \\
\hline Oomplement C3 & $10.7 \div 120$ & $15.1 \pm 8.5$ & $12.8 \pm 8.3$ & $5 \pm 2$ & 39 & \\
\hline LDL Proteln & $9.1 \pm 6.7$ & $7.2 \pm 5.2$ & $8.2 \pm 6.1$ & $\mathrm{NA}$ & NA & \\
\hline Complement $\mathrm{C4}$ & $1.7 \pm 1.5$ & $2.3 \pm 2.0$ & $2.0 \pm 1.8$ & NA & $\mathrm{NA}$ & \\
\hline Immunoglobul in A & $5.7 \pm 5.1$ & $10.7 \pm 11.1$ & $8.1 \div 8.9$ & $\mathrm{NA}$ & NA & \\
\hline Immunoglobul in $M$ & $3.1 \pm 3.1$ & $2.6 \pm 2.3$ & $2.8 \pm 2.7$ & $\mathrm{NA}$ & $\mathrm{NA}$ & \\
\hline 22-Macroglobul in & $2.4 \pm 2.2$ & $2.4 \div 3.5$ & $2.4 \pm 3.0$ & NA & NA & \\
\hline Haptoglobin & $.99 \pm 2.7$ & $.92 \pm 1.9$ & $.96 \pm 2.3$ & NA & NA & . \\
\hline
\end{tabular}

* Represents means of individual calculated rattos for 105 samples tested, using mean values for $14-22$ weeks.

** Based on values from a normal adult, non-pregnancy pool.

*** Based on data from Gitlin. 
TABLE 2

PAM POSITIVE AMNIOTIC FUID SAMPLES FROM 15 NOFMAL PRDGNANCIES $14-22$ WEEXS GESTATION (ALL VALUES IN MG/L)

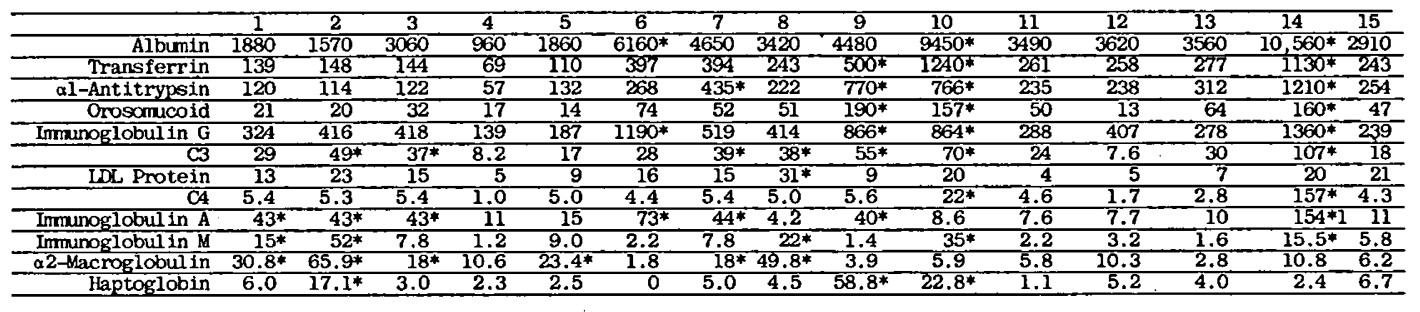

* >3SD ABOVE THE MEAN

TABLE 3

AMNIOTIC FUUID PROTEIN RATIOS FOR PAM POSITIVE SAMPLES IN THE 15 NORMAL PRBGNANCIES (ALL VALUES X $10^{3}$ )

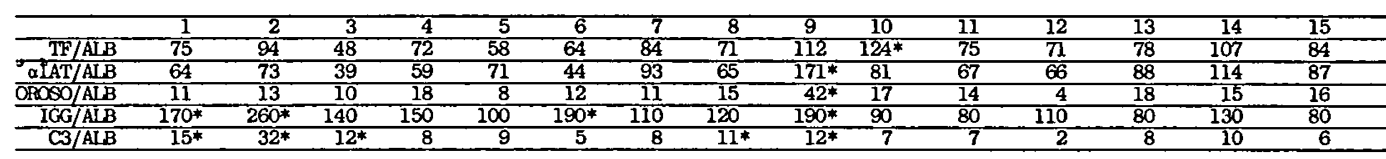

* >3SD ABOVE THE MEAN aBbreviations:

$$
\begin{aligned}
\text { TF } & =\text { Transferrin } \\
\text { alAT } & =\text { al-Ant 1trypsin } \\
\text { OROSO } & =\text { Oroscomucoid } \\
\text { ALB } & =\text { Albumin }
\end{aligned}
$$

\begin{tabular}{|c|c|c|c|c|c|c|c|c|c|c|c|}
\hline & 1 & 2 & 3 & 4 & 5 & 6 & 7 & 8 & 9 & 10 & 11 \\
\hline Albumin & 2530 & 2800 & 3670 & 4410 & 4540 & 4650 & 4850 & $6380 *$ & $6920 *$ & $7050 *$ & $7780 *$ \\
\hline Transferrin & 193 & 149 & 188 & 292 & 320 & 188 & 323 & 334 & 270 & 262 & $497^{*}$ \\
\hline al-Ant1trypsin & 276 & 266 & 335 & 396 & 300 & 357 & 255 & $426 *$ & $493^{*}$ & 191 & $622 *$ \\
\hline Orasomucoid & 39 & 22 & 67 & 28 & 49.2 & 48 & 27 & 51 & 27.6 & 48.6 & $117 *$ \\
\hline Immunoglobul in G & 404 & 266 & 331 & 436 & 502 & 470 & 489 & 696* & 238 & 289 & $664^{*}$ \\
\hline Complement C3 & 24 & 12 & 24 & 24 & 15 & 26 & 26 & 30 & $7.2 *$ & 268 & $44 *$ \\
\hline Low Density Lipoprotein & n $40^{*}$ & $52 *$ & $38 *$ & $40 *$ & 10.9 & $90 *$ & $54 *$ & 15.2 & $62.4 *$ & $54.8 *$ & $76^{*}$ \\
\hline Complement C4 & 2 & 2 & 4 & 4 & 0 & 0 & 2 & 4.0 & $7.6 *$ & 2.4 & 2 \\
\hline Inmunoglobul in A & 8 & 12 & 8 & 6 & 0.8 & 12 & 6 & 0 & 0 & 0 & 0 \\
\hline Immungglobul in M & $28 *$ & $16^{*}$ & $22 *$ & $14^{*}$ & 6.4 & $30 *$ & 20* & 4.8 & 6.4 & 2.8 & 12 \\
\hline Q2-Macroglobul in & 0 & $36 *$ & 6 & $18^{*}$ & 7 & $44 *$ & 10 & 7.4 & $97 *$ & 10 & $68 *$ \\
\hline Haptoglobin & 0 & 0 & 0 & 0 & 1.1 & 0 & 0 & 0 & 0.4 & 0 & 0 \\
\hline
\end{tabular}

TABLE 4

AMNIOTIC FUID PROTEIN LEVELS IN 11 CASES OF ANENCEPHALY DURING THE SECOND TRIMESTER (ALL VALUES IN MG/L)

Pregnancy-associated Macroglobulin not present in any of the 11 sanples.

\begin{tabular}{|c|c|c|c|c|c|}
\hline & 1 & 2 & 3 & 4 & 5 \\
\hline Albumin & 2210 & 2680 & 1030 & 3670 & 2100 \\
\hline Transferrin & 138 & 161 & 112 & 180 & 183 \\
\hline al-Ant1trypsin & 168 & 168 & 117 & 208 & 185 \\
\hline Orosomucold & 22 & 20 & 28 & 42 & 32 \\
\hline$\underline{I g G}$ & 213 & 146 & 92 & 346 & 278 \\
\hline C & 8 & 8 & 10 & 17 & 17 \\
\hline LDL & $52 *$ & 2 & 22 & $40 *$ & $72 *$ \\
\hline$\underline{C 4}$ & 2 & 0 & 0.4 & 2.4 & 3 \\
\hline IgA & 14 & 1 & 5 & 8 & 9 \\
\hline IgM & 22 & 5 & $1.6 *$ & 5 & $12 *$ \\
\hline Q-Macroglobin & 10 & 1.2 & $16 *$ & $12 *$ & 6 \\
\hline Haptoglobin & 0 & 0 & 0 & 0.4 & 0.2 \\
\hline
\end{tabular}

* = 99th percentile by "best 11 t" analysis.

TABLE 5

AMNIOTIC FWID PROTEIN LEVEIS IN 5 CASES OF SPINA BIFIDA DURING THE SEOOND TRIMESTER

Pregnancy-associated macroglobulin not present in any of the 5 samples.

* $=>99$ th percentile by "best $f 1 t$ " analysis. 
TABLE 6

AMNIOTIC FLUID PROTEIN CONCENIRATIONS IN 3 CASES OF FETAL DEMISE

(ALL VALUES IN MG/L)

\begin{tabular}{lccc} 
& A & B & C \\
Albumin & 3590 & 5170 & $8120^{*}$ \\
\hline Transferrin & 290 & 350 & $544^{*}$ \\
\hline al-Antitrypsin & 246 & 404 & $474^{*}$ \\
\hline Orosomucoid & 10.4 & 9.6 & 25.6 \\
\hline Immunoglobulin G & 246 & 456 & $914^{*}$ \\
\hline Complement C3 & 10 & $40 *$ & $60 *$ \\
\hline Low Density Lipoprotein & $60 *$ & $80^{*}$ & $170 *$ \\
\hline Complement C4 & 0 & 0 & 0 \\
\hline Immunoglobulin A & 0 & 0 & 0 \\
\hline Immunoglobulin M & 0 & $30 *$ & $50 *$ \\
\hline I-Macroglobulin & 0 & $40 *$ & 10 \\
\hline Haptoglobin & 0 & 0 & 0 \\
\hline
\end{tabular}

* = 99th percentile by 'best fit" analysis.

0031-3998/78/1203-0243\$02.00/0

Copyright $(0) 1978$ International Pediatric Research Foundation, Inc.

Printed in U.S.A. 